\title{
Social concept of gender socialization of girls in the interpretation of Yaroslavl women
}

\section{E. V. Mikhailova ${ }^{1}$}

1Yaroslavl State Pedagogical University named after K. D. Ushinsky, 108/1 Respublikanskaya str., Yaroslavl 150000, Russian Federation

DOI: $10.18255 / 2412-6519-2020-2-162-175$

Research Article

Full text in Russian

Based on the materials of two series of leitmotiv in-depth interviews - with mothers of girls and kindergarten teachers - the article analyzes the content and orientation of the social concept of girls's gender socialization that is relevant for Yaroslavl. The category "social concept of gender socialization" was introduced to distinguish between scientific generalizations of the content of gender socialization and its social interpretation. An analysis of the social concept of gender socialization was carried out according to such substantial components as ideas about the boundaries of socially acceptable and permissible in behavior, the appearance of girls; observations about the direction of games and favorite toys; regulatory views about femininity, qualities necessary for a woman; parental requirements system to girls, differences in the upbringing of girls and boys, qualities that need to be formed in girls. The concept is presented in two temporal perspectives - informants the study participants talked about their own childhood and how it is now necessary to educate girls. The traditional orientation of the conceptualization of gender socialization by Yaroslavl women has been revealed, according to which girls must first of all instill the qualities of a mother, wife, and mistress. Concluded about the discrepancy between the value-normative aspects of the concept of socialization of girls with the real life practices of their mothers.

Keywords: conceptualization of childhood, gender role, gender socialization, gender contract, feminnost

INFORMATION ABOUT THE AUTHORS

Mikhailova Elena V. $\quad$ E-mail: nmev649@mail.ru

Candidate of Sciences in Sociology, associate Professor of political science and sociology

For citation: Mikhailova E. V. Social concept of gender socialization of girls in the interpretation of Yaroslavl women // Social'nye i gumanitarnye znanija. 2029. Vol. 6, No 2. P. 162-175. (in Russ.) 


\title{
Социальная концепция гендерной социализации девочек в интерпретации ярославских женщин
}

\author{
Е. В. Михайлова ${ }^{1}$
}

1Ярославский государственный педагогический университет им. К. Д. Ушинского, ул. Республиканская, 108/1, Ярославль, 150000, Российская Федерация

DOI: $10.18255 / 2412-6519-2020-2-162-175$

УДК 316.4

Научная статья

Полный текст на русском языке

На материалах двух серий лейтмотивных глубинных интервью - с матерями девочек и воспитателями детских садов - в статье анализируются содержание и направленность актуальной для г. Ярославля социальной концепции гендерной социализации девочек. Категория «социальная концепция гендерной социализации» введена для разграничения научного обобщения содержания гендерной социализации и его социальной интерпретации. Анализ социальной концепции гендерной социализации производился по таким содержательным составляющим, как представления о границах социально приемлемого и допустимого в поведении, внешнем облике девочек; наблюдения о направленности игр и любимых игрушках; нормативные представления о женственности, качествах, необходимых женщине; система родительских требований к девочкам, различия в воспитании девочек и мальчиков, качества, которые необходимо сформировать в девочках. Концепция представлена в двух временных ракурсах - информанты - участницы исследования говорили о собственном детстве и о том, как сейчас необходимо воспитывать девочек. Выявлена преимущественно традиционная направленность концептуализации гендерной социализации ярославскими женщинами, согласно которой девочкам необходимо прежде всего прививать качества матери, жены, хозяйки. Сделан вывод о расхождении ценностно-нормативных аспектов концепции социализации девочек с реальными жизненными практиками их матерей.

Ключевые слова: концептуализация детства, гендерная роль, гендерная социализация, гендерный контракт, феминность

ИНФОРМАЦИЯ ОБ АВТОРАХ

Михайлова Елена Валерьевна

Email: nmev649@mail.ru

Кандидат социологических наук, доцент кафедры

политологии и социологии

Для цитирования: Михайлова Е. В. Социальная концепция гендерной социализации девочек в интерпретации ярославских женщин // Социальные и гуманитарные знания. 2020. Том 6, № 2. С. $162-175$.

(C) Михайлова Е. В., 2020

This is an open access article under the CC BY-NC-ND license (http://creativecommons.org/licenses/by-nc-nd/4.0/) 


\section{Введение}

Социальное значение и содержание детского периода по-разному осмысливается представителями различных поколений, что позволяет говорить о специфичной концепции детства у каждого поколения [1]; в связи с этим можно предположить, что и гендерные аспекты концептуализации детства будут дифференцированы у разных поколений. Задача данной статьи - проанализировать гендерную составляющую актуальной на сегодняшний день концепции детства в отношении воспитания девочек, рассмотрев ее через категорию «социальная концепция гендерной социализации».

Под гендерной социализацией в социальной психологии и социологии понимается процесс усвоения норм, правил поведения, установок в соответствии с социокультурными представлениями о роли, положении и предназначении мужчины и женщины в обществе. В ходе гендерной социализации усваиваются сформировавшиеся в культуре представления о том, как следует вести себя мальчику и девочке, юноше и девушке, какими личностными качествами должны обладать мужчины и женщины [2]. Если психологический подход к исследованию гендерной социализации предполагает прежде всего изучение механизмов этого процесса - таких как научение, подражание и т. д., то социологический акцентирует внимание на содержательной сути и факторной обусловленности гендерной социализации: рассматривает, какие гендерно окрашенные роли, нормативные представления и модели поведения транслируются и как они соотносятся с актуальным состоянием общества и тенденциями его развития. Представления о целесообразной направленности и содержании гендерной социализации, складывающиеся в конкретный временной период в конкретном обществе, можно обозначить понятием «социальная концепция гендерной социализации». Аналогичной по содержанию социологической категорией является «модель гендерной социализации», однако она является своего рода идеальным типом, продуктом научного теоретического обобщения в отличие от категории «социальная концепция гендерной социализации», которая строится на представлениях людей.

Все содержательные модели гендерной социализации можно классифицировать на два базовых типа: первый тип представляют «традиционные», или патриархатные модели, второй - либеральные, или партнерские [3]. Эталонной моделью первого типа является модель семьи Н. Белла и Э. Фогеля, построенная на основных положениях структурно-функционального анализа Т. Парсонса [4]. Данная модель предлагает социализировать мальчика как будущего работающего главу семьи, которому необходимы лидерские качества, достижительная мотивация, контроль над эмоциями, рациональность, ответственность. Девочка должна стать идеальной домохозяйкой и хорошей матерью, проявлять эмпатию, тщательно следить за своей внешностью и домом, быть эмоционально вовлеченной в жизнь мужа и детей, создавать в семье благоприятную психологическую атмосферу. Модели второго типа достаточно вариативны $[4 ; 5 ; 6]$ - от требований вовсе отказаться от гендерной направленности воспитания и предоставить ребенку время для осознания и свободного выбора пола и гендера до более сглаженных вариантов, проповедующих внимание к индивидуальным потребностям и склонностям каждого ребенка, отказ 
от жестких директивных воздействий по принципу «ты же мальчик» или «ты же девочка». Оба подхода к гендерной социализации критикуются: первый - за очевидное несоответствие жизненным реалиям, второй - за деконструкцию социальных норм, отсутствие каких бы то ни было внятных представлений о том, как все-таки следует воспитывать мальчика или девочку.

Исследовательский интерес к гендерным аспектам социализации девочек обусловлен существующим парадоксом: с одной стороны, описывая современное российское общество, демографы и социологи фиксируют кризис современной семьи, фактическую вариативность ее моделей, распространенность индивидуалистических установок у современных россиян, размывание гендерных стереотипов, либерализацию гендерных ролей [7; 8]; с другой стороны, система социальных ожиданий и нормативных представлений россиян о мужественности и женственности, идеальной семье, качествах мужа и жены является поразительно устойчивой и по большей части неизменной в течение всего того периода, когда в СССР и современной России проводились социологические замеры по данной проблематике. Так, от мужчины требуются в первую очередь качества добытчика и защитника, от женщины - быть хорошей матерью и хозяйкой, работа и заработок для женщины, как правило, признаются вторичными, но в целом необходимыми [9]. Такие социальные представления о содержании мужских и женских социальных ролей соотносятся с доминирующими и по сей день гендерными контрактами «кормильца семьи» и «работающей матери». В данной связи представляется важным выяснить, какой подход к воспитанию и социализации девочек практикуется в современных российских условиях сохранения идеала «традиционной» женственности, который становится все труднее реализовать.

\section{Методы}

Данная работа сконцентрирована на анализе концептуализации гендерной социализации девочек на примере г. Ярославля. Интерпретацию этой концепции дали жительницы г. Ярославля - матери несовершеннолетних девочек. С ними было проведено 29 лейтмотивных глубинных интервью на тему «Особенности воспитания и социализации девочек», в выборку попали женщины в возрасте от 23 до 49 лет. По аналогичной проблематике были проинтервьюированы также 37 сотрудниц ярославских детских дошкольных учреждений из числа воспитателей, музыкальных руководителей, методистов. Исследование проводилось с октября по декабрь 2019 года.

В качестве базовых элементов концепции гендерной социализации девочек рассматривались:

- границы социально приемлемого и допустимого в поведении, внешнем облике девочек;

- направленность игр и любимые игрушки;

- опыт, умения, навыки, которые передаются девочкам в семье;

- внешность как составляющая самооценки, ролевые модели для подражания и эталоны красоты, комплексы, связанные с внешностью;

- нормативные представления о женственности, качествах, необходимых женщине; 
- система родительских требований к девочкам, различия в воспитании девочек и мальчиков, представления о качествах, которые необходимо сформировать в девочках.

Концепция представлена в двух временных ракурсах: информанты - участницы исследования говорили о собственном детстве и о том, как он сейчас воспитывают своих дочерей.

\section{Результаты}

\section{Границы социально приемлемого и допустимого в поведении,} внешнем облике девочек

Участниц исследования просили вспомнить, при каких обстоятельствах и в связи с чем взрослые говорили им в детстве «ты же девочка». Также просили вспомнить ситуацию, когда они сами увещевали кого-либо фразой «ты же девочка». Упрек или увещевание «ты же девочка» рассматривались как устойчивый элемент социальной аргументации, выстроенный исключительно по принципу принадлежности к женскому полу. И в первом, и во втором случае спектр ответов был практически одинаков и включал в себя проявления неаккуратности, грубость и сквернословие, участие в драках, предпочтение мальчишеской компании и опасных игр, манеру одеваться «как мальчик». «Фразу «ты же девочка» в детстве я иногда слышала. Чаще всего это было из-за того, что большую часть времени я проводила на улице с мальчишками. С мальчишками мы играли в «войнушку», в стрелялки. У нас были также деревянные пистолеты. Не знаю, почему меня интересовали такие игры... Но мне нравилось это занятие. Поэтому-то мама часто говорила мне: «Вот чем ты занимаешься, что это за игры такие, ты же девочка у меня, а играешь с мальчиками в стрелялки и войнушки!» Была также ситуация, когда мне бабушка сказала: «Ну что же ты такая неаккуратная, ты же девочка, а ведешь себя, как грязнуля». Это было тогда, когда я испачкала свое новое сиреневое платье, подаренное мне бабушкой. Точно не помню, в какой это ситуации произошло, но то, с каким выражением сказала мне это моя бабушка, - это врезалось в память навсегда» (информант - учитель, 42 года, дочери 16 лет). «Да, приходилось слышать - «ты же девочка», тебе нельзя драться с мальчиками. Примерно так» (информант - 41 год, врач, дочери 17 лет). «Мы росли, и в нашей компании было больше мальчиков, конечно, хотелось подражать. Естественно, мама мне много раз говорила: «Лена, что ты там на велосипеде с ними гоняешь? Ободранные коленки, те же девочка, будь поспокойнее». И вот всегда - «ты же девочка», «ты же девочка» (информант - 48 лет, медсестра, дочери 11 лет). Интересны и пояснения тех, кто слов «ты же девочка» в детстве не слышал: «Нет, мне такого никогда не говорили, потому что я всегда была очень аккуратная девочка, всегда следила за своим внешним видом, даже туфли всегда мыла и протирала так, чтобы они блестели» (информант - бухгалтер, 46 лет, дочери 9 лет).

Как уже отмечалось, контекст увещевания «ты же девочка» в современной ситуации не изменился. «Я сама говорила эту фразу девочкам в своей группе, когда они гуляли и пачкались на улище» (информант - 27 лет, воспитатель детского сада). «Да, говорю такое, когда дети начинают себя плохо вести, баловать, кривляться» 
(информант - 27 лет, воспитатель детского сада, две дочери 8 лет и 1 год). «Говорила такое дочке, когда она ходила по лужам и грязи, что девочки должны быть чистыми и аккуратными» (информант - 27 лет, воспитатель детского сада, дочери 3 года).

Некоторые участницы исследования в возрасте 23-30 лет отметили, что их когда-то очень раздражала фраза «ты же девочка» как аргумент взрослых и сейчас они сами никому так не говорят.

В интервью с родителями и воспитателями обсуждался также вопрос о том, какими способами девочка может защитить себя от агрессии и как они сами защищали себя в детстве. У матерей нет единой позиции по данному вопросу, они высказывали полярные мнения. Некоторые говорили о недопустимости драк и установки «дать сдачи». Другие настаивали на том, что в любом случае необходимо «постоять за себя», будь ты мальчик или девочка. «Если в детстве или в подростковом возрасте Вы сталкивались с агрессией со стороны сверстников, как Вы себя защищали? - В основном я их игнорировала, чтобы им неинтересно было мне что-либо говорить. Иногда я могла и ударить, например, щелбан в лоб, но это только если меня очень сильно доводили, была бойкой. Если не могла больще терпеть, то могла ответить им в жесткой форме, благо язык подвешен был» (информант - педагог дополнительного образования, 49 лет, дочери 14 лет). «Ну, когда маленькая была, и подраться конечно могла, всегда отвечала, если меня кто-то обзывал. Да что уж скрывать, я и сама могла кого-нибудь поддеть, задирой была в какой-то степени. Когда стала постарше, ссор старалась избегать, зачем они мне?» (информант - горничная, 48 лет, младшей дочери 11 лет). «Бывало, сталкивалась (с агрессией). Переживала. Жаловалась, бывало, но жаловалась подругам скорее. Защищаться - никак не защищалась, убежать могла. Драться я не дралась, не умела. Словами могла ответить только если, уговорами. Иногда старалась переводить в шутку» (информант - швея, 43 года, дочери 14 лет). «К дракам я отношусь крайне негативно и считаю, что все вопросы можно решить словами. Учитывая, что я женщина, я в драки никогда не влезала и всегда их остерегалась, даже если возникали накаленные моменты. Я считаю, что человек всегда должен быть адекватен и держать себя в руках, вне зависимости от того, женщина это или мужчина. Я предпочитала стоять в стороне, чем являться потом домой с синяками и царапинами. Ни в каких драках я никогда не участвовала, так как могу защитить себя словесно» (информант - диспетчер пекарни, 44 года, есть дочь 16 лет). «Как Вы считаете, может ли девочка драться? - Нет, я считаю, когда девочки дерутся - это выглядит просто отвратительно. Драка вообще отвратительна сама по себе. Когда дерутся мужчины - это еще както... Все равно, конечно это плохо воспринимается, но когда дерутся девочки это просто ужасно» (информант - неработающая домохозяйка, 48 лет, младшей дочери 13 лет).

Вполне ожидаемо, что информанты-воспитатели оказались единодушны в том, что как девочкам, так и мальчикам нужно защищать себя словесно и не вступать в драку. Вместе с тем дети, по словам воспитателей, демонстрируют самые разные модели взаимодействия с окружающими вне зависимости от пола: «Некоторые гиперактивные девочки обижают как девочек, так и мальчиков, отбирают у них игрушки или телефон. У многих детей нет никакого барьера для проявления агрессии, часто мальчики впервые слышат в детском саду, что нельзя обижать и тем более бить девочек» (информант - 43 года, воспитатель детского сада, дочерям 14 и 6 лет). 


\section{Направленность игр и любимые игрушки}

В качестве собственной любимой игрушки участницы исследования упоминали чаще всего куклу и достаточно часто - мягкую игрушку. И в том, и в другом случае, как правило, называли имя игрушки: «кукла Саша», «тигренок Плоша», «собака Чапа», «бегемот Бо-бо», «пингвин Тятя», что говорит об очеловечивании игрушки, выстраивании с ней личных отношений. Многие рассказывали о настоящем культе, сверхценности красивой куклы в их детстве. "Также моей любимой игрушкой была кукла, которая говорила «ма-ма». Мне привезла ее из Болгарии двоюродная сестра Лариса. Она была такая большая и так была похожа на живого ребеночка, живую девочку. Как я тогда была счастлива! Просто не передать словами! Она была в красном платье в белую клеточку, в белых носочках и в белых туфельках. У нее еще были длинные темно-коричневые волосы, которые я очень любила заплетать. А также у нее были большие голубые глаза с ресничками, с длинными густыми ресничками. Она была такая мягкая, ручки и ножки у нее сгибались, ну словно живая! Удивительно, что я помню такие мелочи до сих пор! - Скажите, как Вы играли с куклой? - С куколкой обращалась как со своей дочкой: плела ей косички, шила одежду, делала уколы, лечила ее, укладывала спать, поила и кормила из детской пластмассовой посудки» (информант - учитель, 42 года, дочери 16 лет). «У меня было несколько немецких кукол в детстве, всегда, сколько себя помню, отличала их от наших, советских. В свободной продаже в магазине гдровских кукол не было, их как-то сложным путем доставали. Как-то лет в 6 я принесла в садик немецкую куклу, все девочки стали просить поиграть. Помню, мне жалко было ее кому-то давать, но приятно было, что все обратили внимание, и, наверное, позавидовали. Но больше я ни в садик, ни во двор своих кукол не выносила, очень их берегла, шила на них наряды, делала прически» (информант - 43 года, муниципальный служащий, дочери 11 лет). Участницы исследования говорят о двух основных ролевых вариантах куклы в их детстве: кукла-ребенок-дочка и кукла - эстетический эталон, модель для подражания (в советский период кукла-невеста, в более поздний - кукла Барби). Эти ролевые модели взаимодействия с куклами позволяют «проиграть» в детском возрасте роль матери, хозяйки, формируют эстетический идеал внешности и практики ухода за собой.

Мамы и воспитатели отмечают, что сейчас девочки меньше любят и ценят кукол, чем они сами в детстве, как правило, не отдают им явного предпочтения среди других игрушек. Большинство участниц исследования констатировали, что любимой игрушкой современных детей вне зависимости от пола без сомнения являются телефон или планшет, позже - компьютер; снижается интерес к предметной игре. "Девочки сейчас в основном играют в гаджеты и мало играют с игрушками и в другие игры» (информант - 24 года, мама девочки 3 лет, находится в отпуске по уходу за ребенком). Отмечается интерес девочек к гендерно нейтральным игрушкам (например, конструктор Лего, интерактивные настольные игры, пазлы) и игрушкам, которые воспринимаются скорее как игрушки для мальчиков - роботам, автомобилям, вертолетам с дистанционным управлением и т. д.

Существенно изменились и сами куклы, а также ролевые модели взаимодействия с ними. «Современные девочки любят тоже играть в куклы, только куклы сейчас другие - монстры, феи, уродцы» (информант - 43 года, воспитатель детского сада, дочерям 14 и 6 лет). О том, что их дочка любит Барби, упомянули только 
две участницы исследования, в качестве более популярных называли кукол серий Монстер Хай, Винкс, Лол, Блайз, принцесс Диснея. Не всем мамам и воспитателям нравится внешний облик этих игрушек: кажутся уродливыми диспропорции размеров частей тела, субкультурная атрибутика и эстетика фильмов ужасов. Информанты сетуют на то, что способы игры с куклами также изменились. «Современные девочки в саду также играют с куклами, но сейчас они бегают от монстров, изображают мультики или компьютерные игры» (информант - 43 года, воспитатель детского сада, дочерям 14 и 6 лет). «В целом замечаю тенденцию покупки серийных игрушек (коллекционных) - каких-либо героев мультфильмов, но игр с этими игрушками нет. Сам факт, что они имеются» (информант - 26 лет, воспитатель детского сада, дочери 1,5 года). Некоторые воспитатели в контексте игры в куклы отметили, что игра в дочки-матери во многих группах является постановочной то есть правила и роли этой, казалось бы, самовоспроизводящейся детской игры устанавливают и распределяют воспитатели. Таким образом, кукла-дочка и кукламодель для подражания занимают в предпочтениях современных девочек далеко не первые позиции, им интереснее примерять на себя при помощи кукол образы многочисленных персонажей виртуального мира - мультфильмов и компьютерных игр.

Участницам исследования задавался также вопрос о любимых коллективных играх их детства и играх современных детей. Вспоминая детство, участницы исследования упоминали как скорее «девочковые» игры - дочки-матери, магазин, «игра в классики», так и те, в которых мальчики и девочки принимали участие в равной степени - догонялки, вышибалы, казаки-разбойники, прятки, «войнушка» и т. д. Говоря о современных девочках, информанты констатировали, что в целом дети меньше принимают участия в коллективных играх, чем они сами в детстве, поскольку меньше гуляют, сидят дома с телефоном, компьютером и т. д. Наиболее информативными здесь стали интервью с воспитателями детского сада, поскольку распорядок дня в дошкольном учреждении предусматривает коллективные игры как постановочного, так и спонтанного характера (т. е. те, в которые дети играют «сами по себе», игра не организуется воспитателями). Воспитатели отметили, что большая часть игр носит совместный характер - в них в равной степени участвуют и мальчики, и девочки. Подвижные игры - прятки, догонялки, казаки-разбойники в целом остались теми же, какими были в их собственном детстве. В качестве популярных ролевых спонтанных игр современных девочек-дошкольников воспитатели назвали игру в салон красоты или парикмахерскую, игру «Кухня». Примечательно, что в игре «Кухня» детьми копируются популярные сюжетные телепередачи о ресторанном бизнесе и кулинарии, а не приготовление еды дома мамой или другими взрослыми. Отвечая на вопрос о том, какие домашние ситуации дошкольники все-таки спонтанно «проигрывают», находясь в детском саду, воспитатели отмечали, что таких разыгрываемых в игре ситуаций вообще мало, поскольку родители проводят с детьми слишком мало времени. Достаточно редко игра воспроизводит диалог родителей с детьми, несколько чаще - жесткие воспитательные моменты, такие как окрики, шлепки. Одна воспитательница припомнила спонтанную коллективную ролевую игру, в которую дети, по ее словам, с удовольствием играют по понедельникам до обеда: «Вот сколько раз наблюдала, придут в понедельник, рассядутся за столом и что-то как бы разливают, произносят тосты, чокаются и так далее. Долго могут так сидеть. В общем, понятно сразу, у кого 
чем родители в выходные занимаются...» (информант - 38 лет, воспитатель детского сада, есть дочь 14 лет). Общим местом в интервью с воспитателями стало их обвинение современных родителей в том, что задачу воспитания и развития своего ребенка они предпочитают полностью возложить на детский сад и разнообразные центры дополнительного развития. «Как-то услышала разговор двух мам в раздевалке, одна другой жалуется, что ребенка долго, до трех с половиной лет в детский сад не брали, поэтому, вот, как считает мама, он у них и не разговаривал» (информант - 32 года, воспитатель детского сада, есть дочь 9 лет).

\section{Опыт, умения, навыки, которые передаются девочкам в семье}

Все без исключения информанты говорили, что от своих мам и бабушек переняли навыки уборки и приготовления еды. «Как раз моя мама много внимания уделяла домашнему хозяйству, готовке, уборке. Вот эти навыки я у нее и переняла. Когда я была маленькая, мы с мамой постоянно осваивали новые рецепты. Уборка квартиры - этот навык я тоже, несомненно, переняла у своей мамы, она с детства меня к этому приучала, пыталась этому научить. То есть от мамы я переняла умение вести домашнее хозяйство и умение создавать в доме уют» (информант - диспетчер пекарни, 44 года, есть дочь 16 лет). Многие отмечали, что помимо базовых бытовых навыков научились шить или вязать. Некоторые говорили о целенаправленном формировании художественного вкуса в их семье, который, по мнению большинства информантов, проявляется прежде всего в умении хорошо одеваться. «Ваши родители, бабушки, дедушки каким-то образом прививали Вам хороший вкус? - Родители с детства меня одевали очень хорошо. Я не помню такого, чтобы мне мама что-то купила и мне не понравилось это. Из одежды. Постоянно, если она мне что-то купит. Принесет, спрашивает меня: «Лен, тебе это нравится?» Я говорю: «Да, да». Потому что у моей мамы хороший вкус, начнем с этого. И вот, с годами у меня сформировался свой вкус. Я знаю, что как надеть, чтобы не выглядело сильно вычурно, смешно, тем более нужно это с фигурой как-то подобрать, чтобы не выглядеть нелепо. Я считаю, у меня не очень плохой вкус» (информант - 41 год, врач, дочери 17 лет). Формирование вкуса информанты напрямую связывают с материальным достатком своей родительской семьи, ее потребительскими возможностями: «Целенаправленно это не делалось (формирование вкуса). Этот вкус воспитывался, глядя на их поведение, стиль одежды. Да и про одежду нет смысла говорить. Был дефицит разноцветных тканей, модной то время одежды. Поэтому и вкус был ориентирован на то, что было» (информант - 45 лет, учитель, младшей дочери 10 лет). Единичными были упоминания о том, что родители водили их в детстве в музеи, на концерты, экскурсии.

Информанты говорили, что кулинарные навыки и навыки уборки они пытаются передавать своим дочерям, как и манеру одеваться, собственные представления о хорошем вкусе. Навыки ручного труда, прежде всего шитья, информанты признали излишними и малоактуальными ввиду нынешнего изобилия одежды. Многие отметили, что на попытки привить хороший вкус в одежде их девочки зачастую реагируют обвинениями в отсталости, отсутствии понимания современной моды.

Задавался также вопрос о воспроизводстве внутри семьи практик ухода за собой. Выяснилось, что здесь имеет место скорее «обратная преемственность»: современные девочки-подростки являются наиболее продвинутыми пользователями 
beauty-индустрии, и их мамы перенимают у них многочисленные косметические новинки. Если сравнивать процедуры ухода и макияжа «мам»с тем, как ухаживали за собой бабушки современных девочек, они также оказываются более трудоемкими и разнообразными. «А по сравнению со своей матерью Вы уделяете больше или меньше внимания себе, своей внешности? - Я думаю, что я больше уделяю. Мой отец никогда не разрешал ей краситься, и прочего такого у нее не было. Он считал ее очень красивой женщиной, и это было для него лишним. Она до сих пор не умеет красить губы, а я вот каждый день крашусь. Исключение только выходные дни, когда никуда не идешь» (информант - 48 лет, психолог, младшей дочери 17 лет). «Моя мама никогда не красилась, по крайней мере, в период замужества, она считала это не очень важным. Я же уделяю себе гораздо больше внимания, и крашусь, и хожу к косметологам» (информант - 35 лет, неработающая домохозяйка, дочери 9 лет). «Конечно, по сравнению со своей мамой я уделяю больше внимания таким моментам, потому что раньше было другое время, то есть когда я была маленькая, индустрия красоты не была так развита, как сейчас, не было ни салонов красоты, ни процедурных кабинетов, где можно корректировать свою внешность. Опять же в советское время одежда была однотипной и похожа друг на друга, а в наше время это все сильно изменилось, появились различные косметические кабинеты, стал более доступен спорт для обычных людей» (информант - диспетчер пекарни, 44 года, есть дочь 16 лет). «Мне кажется, в жизни моей мамы не было никаких процедур по уходу, а у меня были и массаж, и физкультура, процедуры для лица, мезороллер» (информант - 41 год, врач, дочери 17 лет).

\section{Внешность как составляющая самооценки, ролевые модели для подражания и эталоны красоты, комплексы, связанные с внешностью}

Содержание глубинных интервью с мамами современных девочек заставляет задуматься о кардинальном сдвиге в восприятии внешности, который они пережили в детстве и в подростковом возрасте. Значение внешних качеств женщины было переоценено, внешность стала предметом соревнования, приложения усилий, целенаправленной работы по улучшению себя, источником комплексов, важнейшей составляющей идентичности женщины. Примечательно, что инициатором такого сдвига вовсе не были родители информантов, он, очевидно, имел социальное происхождение. Информанты отмечали, что их родители относились и к собственной внешности, и к внешности своих детей гораздо проще, она явно не обладала для них статусом сверхценности. «Скажите, случались ли у Вас в детстве или в подростковом возрасте неприятные переживания, комплексы из-за собственной внешности? - Они и сейчас есть. Это как было, так и осталось все. Внешность - это прямо бич. Это с детства. Не такие ноги, не такие руки, не такие волосы, не такой нос, отсутствие талии, то есть это было, несмотря на то, что мне всегда говорили: «да что ты, да как ты». И это до сих пор есть, хотя я знаю, что выгляжу хорошо. Но оно есть. - А знали родители о таких Ваших комплексах? - Знали. Но почему-то в наше время было не принято говорить о том, что у тебя есть какие-то комплексы во внешности, и другие какие-нибудь комплексы, то есть человек был рожден, чтобы созидать, поднимать, бороться, идти «с красным флагом вперед» независимо от собственных каких-то личных переживаний. Но переживания были и комплексы тоже. - Как реагировали родители на Ваши комплексы? - Реакция родителей была. 
Мама, да и папа тоже, все время говорили, что я преувеличиваю, то есть принижаю свои достоинства. Нас не приучали, во всяком случае в моей семье не было такого... Если я и пошла в школу непричесанная, ну и ладно, ничего в этом страшного нет, пошла в колготках, у которых коленки отвисли, ну и ладно, ничего такого. Как-то достаточно спокойно к этому относились. Родители работали день и ночь, поэтому мало замечали это. Но вот, когда я взглянула на свои старые фотографии (где я в подростковом возрасте), я дала себе установку: «Я никогда не буду такой, какая я на фотографии. И никогда не будут такими мои дети». Я не знаю откуда, но чувство вкуса, я думаю, у меня присутствует. Это может быть врожденное или приобретенное, потому что мне всегда нравились французские фильмы, образы французских женщин. Их манера одеваться, чувства вкуса» (информант - бухгалтер, 48 лет, младшей дочери 13 лет).

В качестве эталонных информанты вспоминают образы знаменитых актрис, певиц, никто не назвал эталоном стиля и красоты свою маму. Все подчеркивали, что не стремились никому подражать буквально, но искали ориентиры вне обыденной жизни и своего социального круга - в тех, кого видели в кино или на телевидении.

Про своих дочерей матери говорили, что те беспокоятся и переживают о своей внешности не меньше, чем они сами когда-то. Стандарты красоты и модные элементы внешности нового поколения имеют, по словам информантов, интернетпроисхождение. Эстетику Инстаграма и субкультурную атрибутику матери, как правило, критикуют. Вопрос об образцах для подражания у современных девочекподростков вызывает крайнее раздражение, все они, как говорят матери подростков, усвоили идею собственной уникальности и неповторимости. Матери и дочери, по-видимому, вновь оказались в разных системах эстетических координат, однако и для тех, и для других осознание собственных внешних данных и работа над ними закрепились в качестве важнейшего элемента социализации.

\section{Нормативные представления о женственности, качествах,} необходимых женщине

Система социальных требований к современной российской женщине в интерпретации матерей предстает российским вариантом концепции «woman power». Информанты - представительницы различных социальных групп - сделали акцент на самостоятельности и независимости женщины. «Какие личные качества необходимы современной российской женщине? - Целеустремленность, как в советское время, терпение, умение владеть собой, потому что в наше тяжелое время неумение владеть собой может привести к неприятным последствиям, повернуть женщину «не на ту дорожку». Ведь на женщине и семья, и хозяйство - от этого никуда не уйдешь. Облегчение труда автоматической стиральной машинкой и подачей газа на кухню, например, не спасло женщину, нашу современную женщину от трудностей и семейных, и финансовых. То есть женщине нужно быть терпеливой и, к сожалению, уметь тащить на себе семью» (информант - бухгалтер, 48 лет, младшей дочери 13 лет). «Ну, ум, во-первых, и выживать в этом мире. Доброта, естественно, доброта, любить окружающих людей, относиться ко всем с любовью и пониманием. Вот это самое главное. Ты не только женщина, но и человек. Так, что еще сказать? Быть хорошей мамой и женой» (информант - 48 лет, медсестра, дочери 11 лет). 
«Стрессоустойчивостью должна обладать, в первую очередь, современная женщина. Потому что в наше время один стресс... Трудолюбием должна обладать, целеустремленностью. Доброта, конечно же, должна присутствовать» (информант швея, 43 года, дочери 14 лет). «Упорство, трудолюбие, без него ничего не добьешься, настойчивость, умение подстраиваться под ситуацию, выдержка, уметь владеть своими чувствами и эмоциями. Нужно всегда надеяться только на себя и ни на кого другого, потому что в жизни могут быть любые ситуации» (информант - бухгалтер, 46 лет, дочери 9 лет). «Первое - это уверенность в себе. Второе - пробиваемость. Сама не пробьешься, никто тебе не поможет. Третье - коммуникабельность. Нужно уметь общаться и договариваться с людьми. Ну и, естественно, обаяние» (информант - индивидуальный предприниматель, 45 лет, дочерям 15 и 8 лет). «Независимость в первую очередь, красота и целеустремленность» (информант - продавец, 39 лет, дочери 11 лет).

В ответах воспитателей, напротив, доминируют качества, связанные с реализацией семейной и хозяйственно-бытовой роли женщины, о независимости и самостоятельности упомянули лишь две женщины из 37 в данной категории информантов. «Современной женщине не хватает какой-то мягкости, женственности, но при этом нужно быть уверенной в своих силах, в любой момент постоять за себя и за свою семью. Уделять больше времени себе, близким. Особенно это касается матерей-одиночек» (информант - воспитатель детского сада, 45 лет). «Необходима доброта, любовь к своим детям, желание идти на свою работу, уметь общаться слюдьми, стараться их понять и, если есть возможность, помочь» (информант воспитатель детского сада, 39 лет).

Система родительских требований к девочкам, различия в воспитании девочек и мальчиков, представления о качествах, которые необходимо сформировать в девочках

Ответы информантов на вопрос о качествах, которые необходимо формировать в современных девочках, по своему содержанию несколько отличаются от того набора качеств, который они перечисляли как необходимые современной россиянке. Здесь обе группы опрошенных давали достаточно последовательные ответы в рамках традиционных представлений об основном предназначении женщины и семья, и система дошкольного образования ориентированы на формирование у девочек аккуратности, опрятности, хозяйственных навыков. "Девочки должны больше помогать по хозяйству, прививать им эти навыки, такие как помощь на кухне, уход за своей одеждой, следить за своими вещами, ухаживать за своей внешностью - чтобы выросли хорошими хозяйками» (информант - воспитатель детского сада, 27 лет). «Девочкам нужно прививать любовь и заботу о ближних» (информант - воспитатель детского сада, 25 лет). «Девочек нужно учить быть слабым полом, опрятными, скромными, уважать старших» (информант - воспитатель детского сада, 39 лет, дочери 15 лет). «Считаю, что в современных детях нужно воспитывать те же качества, что и в нас с детства воспитывали родители» (информант - музыкальный руководитель в детском саду, 26 лет). Можно констатировать, что представления воспитателей о том, как именно социализировать современных девочек, последовательны, целостны и внутренне непротиворечивы: без сомнения, их сле- 
дует воспитывать как будущих матерей и хозяек, что полностью согласуется с набором социальных требований к современной российской женщине в интерпретации этой категории информантов.

Родители интерпретировали систему требований к современной россиянке как гораздо более разнообразную, она включала в себя и самостоятельность, и качества жены и матери, и умение зарабатывать деньги, и требования к внешности. Тем не менее, говоря о том, какие именно качества они стараются формировать в своих дочерях, матери в большинстве случаев ограничивались упоминанием качеств, необходимых для реализации семейной роли женщины. Возможно, такое несоответствие объяснимо тем, что в актуальном общественном дискурсе, в том числе в СМИ, наиболее внятно проговаривается именно эта сторона женственности. Возможно также, что воспитание хозяйственно-бытовых навыков матери воспринимают как сферу своей личной ответственности, а прочие качества, как ожидается, сформируются адекватно требованиям конкретной жизненной ситуации и социальной среды.

Невозможно не обратить внимания на взаимную комплементарность мужских и женских социальных ролей (женская роль не мыслится без мужской), которая отчетливо проступала во всех интервью - рассуждая о том, как воспитывать девочку, информанты обязательно упоминали о мальчиках без специального наводящего вопроса. «По моему мнению, девочку необходимо воспитывать в любви и ласке, потому что в дальнейшем она будет дарить эту ласку своим детям. Мальчика же, я считаю, надо воспитывать немного пожестче, потому что мужчина в дальнейшем станет добытчиком, защитником, главой семьи, поэтому с детства он должен приучаться к самостоятельности и ответственности. Женщина должна создавать уют в доме, воспитывать и любить своих детей» (информант диспетчер пекарни, 44 года, есть дочь 16 лет). «Мне кажется, девочку нужно воспитывать, чтобы по дому помогала, готовить учить, учить тому, что сама умеешь, а то как же она, не знавши ничего, семью строить будет? Мальчишка должен с отцом много времени проводить, как я думаю. Он рыбалке научится, строительству, машину водить. Должен мужественным расти, сильным, храбрым. Любовь, естественно, нужно дарить и тому, и другому» (информант - швея, 43 года, дочери 14 лет). «Девочку надо воспитывать в доброте, ласке, чтобы она чувствовала, что ее любят, мальчика построже. Девочке нужно прививать качества, которые присущи женщине. Учить заниматься домом, за собой ухаживать, она ведь тоже будет мамой и женой. Нужно учить, как следует себя вести, общаться с людьми. Мальчика нужно воспитывать как опору, чтобы он умел делать что-то руками. Я считаю, что женщина должна беречь семью, сәлаживать все, а мужчина должен быть добытчиком и защищать семью» (информант - бухгалтер, 46 лет, дочери 9 лет).

\section{Выводы}

По результатам проведенного исследования можно констатировать, что актуальная для г. Ярославля социальная концепция гендерной социализации девочек является по своему содержанию и направленности традиционно ориентированной. Несмотря на трудности современной жизни, необходимость сочетать несколько функций и ролей, социум продолжает готовить девочек главным образом к реализации своего женского предназначения - роли матери, жены, хозяйки. Вместе с тем 
эта концепция содержит немало противоречий и «белых пятен», наиболее очевидным из которых является противоречие между социальными требованиями к современной россиянке и спроецированной в будущее системой ориентиров воспитания и социализации девочек. Получается, что если современной российской женщине нужны в первую очередь качества, необходимые для выживания, то в будущем женщине почему-то понадобятся совершенно иные качества, произойдет возврат к традиционной женственности. Просьбы пояснить этот парадокс приводили информантов в растерянность и замешательство. Можно предположить, что, поскольку в обществе отсутствует сколь-либо правдоподобная картина будущего и какая-либо иная легитимизированная модель гендерной социализации, кроме традиционной, информанты черпают представления об ориентирах гендерной социализации в мире ценностей - то есть там, где «мужчины мужественны, а женщины - женственны». Нельзя не отметить, что современные девочки как дошкольного, так и более старшего возраста, по наблюдениям информантов, являются совершенно другими, кардинальным образом отличаются от них самих в детстве они погружены в виртуальную среду, у них иной спектр интересов и взглядов на мир, манера общения, новые эстетические идеалы. Портрет нового поколения скорее противоречит, чем соответствует модели традиционной женственности. В данной связи можно предполагать, что разрыв между ценностно-нормативными аспектами гендерной социализации и тем, как она происходит в реальности, будет расти.

\section{Ссылки / References}

1. Михайлова Е. В. Концептуализация детства в жизненных нарративах представителей двух поколений россиян // Социальные и гуманитарные знания. 2019. Том 5. № 1. С. 52-65.

2. Козлов В. В., Шухова Н. А. Гендерная психология. Учебник для вузов. М., 2010. 288 с.

3. Семенова Л. Э. Содержание основных моделей процесса гендерной социализации в современном обществе // Ярославский педагогический вестник. 2009. № 3 (60). C. $143-147$.

4. Здравомыслова Е. А., Тёмкина А. А. 12 лекций по гендерной социологии: учебное пособие. СПб.: Издательство Европейского университета в Санкт-Петербурге, 2015. 768 c.

5. Тартаковская И. Н. Гендерная социология. М., 2005. 369 с.

6. Введение в гендерные исследования. Ч. 1: учебное пособие / Под ред. И. А. Жеребкиной. СПб.: Алетейя, 2001, 700 с.

7. Демографическая модернизация России: 1900-2000 / Под ред. А. Г. Вишневского. М.: Новое издательство, 2006. 601 с.

8. Лежнина Ю. П. Трансформация гендерных ролей в современной России // Общественные науки и современность. 2013. № 4. С. 165-176.

9. Гурко Т. А. Социология пола и гендерных отношений // Социология в России / Под ред. В. А. Ядова. М.: ИС РАН, 1998. С. 173-195. 